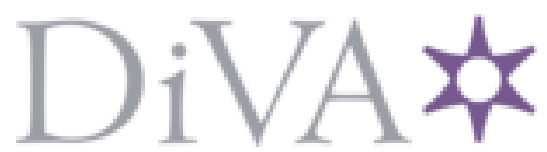

http://www.diva-portal.org

This is the published version of a paper presented at 11th annual International Conference of Education, Research and Innovation, 12-14 November, 2018, Seville, Spain.

Citation for the original published paper:

Hällgren, C. (2018)

Crowdsourcing identities: One way to think about young people's making of identity in conditions proposed by contemporary, digital technologies?

In: L. Gómez Chova, A. López Martínez, I. Candel Torres (ed.), ICERI2O18

Proceedings, 1574 (pp. 2584-2588). IATED Academy

ICERI Proceedings

https://doi.org/10.21125/iceri.2018.1574

N.B. When citing this work, cite the original published paper.

Citation Code: TY - CONF AU - C. Hällgren TI - CROWDSOURCING IDENTITIES: ONE WAY TO THINK ABOUT YOUNG PEOPLE'S MAKING OF IDENTITY IN CONDITIONS PROPOSED BY CONTEMPORARY, DIGITAL TECHNOLOGIES? SN - 978-84-09-05948-5/2340-1095 DO - 10.21125/iceri.2018.1574 PY - 2018 Y1 - 12-14 November, 2018 CI - Seville, Spain JO - 11th annual International Conference of Education, Research and Innovation JA - ICERI2018 Proceedings SP - 2584 EP - 2588 ER -

Permanent link to this version:

http://urn.kb.se/resolve?urn=urn:nbn:se:umu:diva-154276 


\title{
CROWDSOURCING IDENTITIES: ONE WAY TO THINK ABOUT YOUNG PEOPLE'S MAKING OF IDENTITY IN CONDITIONS PROPOSED BY CONTEMPORARY, DIGITAL TECHNOLOGIES?
}

\author{
C. Hällgren \\ Umeå University (SWEDEN)
}

\begin{abstract}
This presentation reports on an ongoing Swedish research project called Crowdsourcing Identities which concerns youth, identity and social media. The making of identity has been endorsed as one important condition for learning for a long time, in both research and educational policy context. It is argued that developing a confident, individual identity, and reflecting upon the identity of others, is fundamental in any educational practice. Moreover, matters of identity intersect with the ongoing digitalization of society in general and education in particular and digital technology proposes conditions for social interaction that differ from those available in pre-digital times. So, these new conditions enable young people not only to represent identity in other ways but also to make and learn about identities in digitally mediated ways - within as well as outside of educational contexts. The overall aim is to conceptually and empirically deepen the knowledge about young people's making of identity, digital technology and learning, as they combine. In focus is also how they may, to various extents in different intersections, influence conditions for teaching and learning. This presentation reports on the conceptual side of the research. It is suggested that one way to think about young people's identity making, when practiced in conditions proposed by contemporary digital technologies, is through the interpretive lens of Crowdsourcing Identities. It draws on existentialism and social constructivism and converge theories about identity, technology and crowdsourcing. By so, it offers one way for thinking about digital technology, such as social media, as spaces not only for representing and expressing identities, but also as mediating conditions for identity making - a practice about existence and not just superficial expressions of vanity.
\end{abstract}

Keywords: identity, digital technology, social media, youth, young people, crowdsourcing, education, communication, media, existentialism.

\section{INTRODUCTION}

Smiling easily, with slightly lowered eyelids, Mary looks straight into the lenses of the little device she holds at arm's length. She seems to be in her teens. Her hair curls down her neck while she tilts her head softly to the side and takes a number of pictures of herself. After carefully selecting and making some adjustments, a picture is uploaded together with her other self-portraits, which she has already shared. Next to this new picture she writes, "I am a bit clueless as to how I look . . . Any suggestions? Also, in which picture do you think I look 'the best'"? Within a few hours, Mary's request has gotten numerous responses.

I often use this brief narrative in writings and lectures to illustrate how one young person can use contemporary digital technologies in a practice about identity. The narrative could be thought of from several perspectives. At first, Mary might appear as engaged in something vain and superficial. Or, it could be thought of as exemplifying old practices self-portrayals, that were and still are performed by technologies such as drawings, paintings, photographs, sculptures and, today; also performed by digital technologies. Further, her practice could exemplify what is called a Selfie, which explained as a cultural symbol [1] of our time, and also widely published. A September 2018 search show that the selfie hashtag retrieves $360 \mathrm{Mn}$ posts on Instagram. The selfie is identified as a genre of its own, where great varieties of human lives such as politics, religion, sports, illness, war, crime, sexuality, pregnancy, funerals, and more are expressed [2], [3], [4], [5], [6], [7].

Returning to the narrative again, Mary publishes carefully composed images of herself, and what is more, she has an audience in mind. She includes explicit requests for feedback on appearance in the caption, and after a while, there is feedback and two-way communications in the commentary field. This suggest that she uses contemporary, digital technology not only to represent and convey identity, but also to invite others in a practice about identity. In this paper it is suggested that one way to think 
about this particular practice is through the lens of Crowdsourcing Identities, a convergence of perspectives of existentialism, social constructivism, technology and ideas of crowdsourcing.

\section{METHODOLOGY}

The paper draws on a conceptual and explorative inquiry that is part of the ongoing Swedish research project called Crowdsourcing Identities and concerns youth, identity and social media. The overall aim of the project is to conceptually and empirically deepen the knowledge about young people's making of identity, digital technology and learning, as they combine, or not. In focus is also how they may, to various extents in different intersections, influence conditions for teaching and learning. In this paper, perspectives of existentialism, social constructivism, technology and ideas of crowdsourcing are converged in four themes, from this Crowdsourcing Identities is outlined as one interpretive lens to think about young people's existential matters of making identity in conditions mediated by contemporary digital technology.

\section{RESULTS}

As said, the aim is to outline of one way for thinking about the making of identity in conditions mediated by contemporary digital technology, from perspectives of social constructivism, existentialism and technology and ideas of crowdsourcing. The results from the analysis were converged into the interpretive lens of Crowdsourcing Identities and concerns the following four themes; The making of identity; The duality of Self and Other; The Gaze as panopticon of evaluative Others, and finally; Identity, technology and crowdsourcing.

The making of identity: By combining perspectives of existentialism and social constructivism [8], [9], [10], [11] the making identity is thought of as a relational practice, essential to exist as someone, rather than as no one. Furthermore, I consider the making of identity as human's continuous requests and answers about being, becoming and belonging. That is; Who am I? How do I appear to others? Who can I be and become? And, where do I belong?

The duality of the Self and Other are thought of as conditional to the practice of making identity. The Other is vital to confirm existence and, also, to human's continuous requests and answers about being, becoming and belonging [12], [13], [14], [15], [16], [17]. Moreover, the Other can be confirmative and communicate approval and appreciation. There might also be absence of recognition. Or the Other can be evaluative [18], [19], [20], [21], [22], [23], [24], [25], [26] [27], [28], [29], [30], [31], [32], [33]. Thus, the duality of Self and Other can involve discriminatory discourses, such as sexism and racism and affect humans' being, becoming and belonging, by so identities are made in normative ways.

The Gaze as panopticon of evaluative Others: To realize the duality of Self and Other, humans need to see each other. Or, existentially speaking, there has to be a Gaze [12], [13], [34], [17], [14], [21], [18], [19]. The Gaze is thought of as more than a look. It is part of the practice of making identity because it realizes the duality of the Self and the Other. Moreover, the Gaze, present or imagined, can involve seeing the Other, to see the Self, to be seen by Others and, also, to see the Self through the Gaze of Others. The Gaze can, additionally, reflect recognition, misrecognition or absence of recognition. As such the Gaze can function as a panopticon [35] of present and imagined evaluative Others in human's continuous requests and answers about being, becoming and belonging.

Identity, technology and crowdsourcing: Technologies, such as theatres, writing, mirrors, cameras, computers, digital networks and social media have inspired, and keep inspiring how identity is thought of in ways that are historically and socially situated. [10], [36], [37], [38], [39], [40], [41], [42], [43], [44], [45], [46], [47], [48]. In this paper it is suggested that contemporary, digital technologies can mediate conditions where, for instance, social interactions about existential matters, such as the making of identity can be practiced in ways that were not possible in predigital times. Technologies, such as social media, can offer extended ways to humans to represent and communicate identities, and also offer extended ways to interact with others and gather information. In multimodal, multidirectional, collaborative and networked ways humans can turn to online crowds of others, ask for feedback, explicit or implicit, and engage in continuous requests and answers about being, becoming and belonging. Who am I? How do I appear to others? Who can I be and become? And, where do I belong? This, I suggest, is a form of crowdsourcing [49], [50], [51], [52], that concerns existential matters of making identity; a crowdsourcing for identity. 


\section{CONCLUSIONS}

Turning to the narrative again, and watching Mary through the lens of Crowdsourcing Identities, the combination of her practice and contemporary digital technology, can be thought of from a convergence of perspectives of existentialism, social constructivism, technology and ideas of crowdsourcing. Contemporary technology can be thought as mediating conditions for the existential practice of making identity, the duality of Self and Other, the Gaze as panopticon of Others, and conditions for engaging online crowds of others in these matters.

Although, technologies are not essential to make identity, it is suggested that they can mediate conditions for identity and, humans may use these conditions - or not. When the making of identity and contemporary technologies combine, the interpretive lens of Crowdsourcing Identities is one way, to think about this. Humans making of identity is rich and complex and can hardly be fully capture by any concept. Thinking about identity making through the lens of Crowdsourcing Identity do not offer a $360^{\circ}$ panorama scenery. It is suggested to cover a partial view of what there is to be seen and represent one way to think about Mary's practice and technology as combined in matters of existence.

\section{REFERENCES}

[1] B. Adewunmi, The Guardian, The rise and rise of the selfie, 2013. Retrieved in 25 September 2018, from https://www.theguardian.com/artanddesign/2013/apr/02/rise-and-rise-of-the-selfie

[2] K. Warfield, C. Cambre and C. Abidin, "Introduction to the Social Media + Society Special Issue on Selfies: Me-diated Inter-faces," Social Media + Society, vol. 2, no 2. 2016. https://doi.org/10.1177/2056305116641344, Retrieved in 3 April 2018.

[3] T. M. Senft, "Micro Celebrity and the Branded Self" in A Companion to New Media Dynamics (J. Hartley, J. Burgess and A. Bruns, eds.) pp. 346-345. (city/state) Blackwell Publishing, 2013.

[4] A. Hess, "The Selfie Assemblage," International Journal of Communication, vol. 9, pp. 16291664, 2016. http://ijoc.org/index.php/ijoc/article/view/3147 Retrieved, 3 April 2018.

[5] E. Losh, "Feminism Reads Big Data: "Social Physics," Atomism, and Selfiecity," International Journal of Communication, vol. 9, pp. 16447-1659, 2015. http://ijoc.org/index.php/ijoc/article/view/3152 Retrieved 3 April 2018.

[6] K. Lobinger and C. Brantner "In the Eye of the Beholder: Subjective Views on the Authenticity of Selfies," International Journal of Communication, vol. 9, pp 1848-1860. 2015 http://ijoc.org/index.php/ijoc/article/view/3151, Retrieved 3 April 2018

[7] J. W. Rettberg, Seeing ourselves through technology: how we use selfies, blogs and wearable devices to see and shape ourselves. New York, NY: Palgrave Macmillan. 2014. https://doi.org/10.1057/9781137476661 Retrieved September 262018.

[8] C. Taylor, Multiculturalism: examining the politics of recognition. (A. Gutmann, Red). Princeton, N.J.: Princeton Univ. Press, 1994.

[9] Z. Bauman, "From Pilgrim to Tourist - a Short History of Identity," in Questions of Cultural Identity (S. Hall, and P. du Gay, eds.), pp. 18-36. London: Sage Publications, 1996.

[10] Z. Bauman, Identity: conversations with Benedetto Vecchi. Cambridge: Polity Press, 2004/2010.

[11] M. Heidegger, Identity and Difference. Chicago, III.: University of Chicago Press, 1969/2002.

[12] S. De Beauvoir, The Second Sex, London: Vintage Books, 1949/2011.

[13] J-P. Sartre, Being and Nothingness: An Essay on Phenomenological Ontology. Routledge, 1943/2005.

[14] Peter L. Berger and Tomas Luckmann, The Social Construction of Reality. Hammondsworth. Middlesex: Penguin Books 1966/1991, and at http://perflensburg.se/Berger\%20socialconstruction-of-reality.pdf Retrieved 26 September 2018.

[15] G. Griffiths, "Other," in: Key Concepts in Postcolonial Studies. (B. Ashcroft, G. Griffiths and H. Tiffin, eds.), London: Routledge, pp. 169-173, 1999.

[16] G. H. Mead, Mind, self, and society: from the standpoint of a social behaviorist. (Edited by C. W. Morris.) Chicago: University of Chicago Press, 1934/1972. 
[17] C. H. Cooley, Human Nature and the Social Order. New York: C. Scribner's sons. 1902. https://ia902707.us.archive.org/35/items/humannaturesocia00cooluoft/humannaturesocia00cool uoft.pdf Retrieved 27 September 2018.

[18] C. Hällgren "Art Blended Research and Children's Gender Identity Making," Journal of Creative Education, Scientific Research Publishing, vol. 6, no. 22, pp. 2333-2350, 2015 a. http://file.scirp.org/pdf/CE_2015122214423626.pdf Retrieved 26 September 2018.

[19] C. Hällgren, "- Be a Man! Art Blended Research to Explore Boys' Gender Making," in: Invisible Boy: The Making of Contemporary Masculinities. (C. Hällgren, E. Dunkels, and G-M. Frånberg, eds.), Umeå University, pp. 17-30, 2015b. And at http://www.invisibleboy.org, Retrieved 26 September 2018.

[20] C. Hällgren, "Gendered Other Hidden Girl," in Invisible Girl (G-M. Frånberg, C. Hällgren, and E. Dunkels eds.) Umeå University, pp. 17-21, 2013a. And at https://iml.edusci.umu.se/invisiblegirl Retrieved 26 September 2018.

[21] C. Hällgren, "The Girlish Condition," in Invisible Girl (G-M. Frånberg, C. Hällgren, and E. Dunkels, eds.) Umeå University, pp. 55-63, 2013b. And at https://iml.edusci.umu.se/invisiblegirl Retrieved 26 September 2018.

[22] C. Hällgren, E. Dunkels and G-M Frånberg, "Exploring the Making of Boys" in Invisible Boy: The Making of Contemporary Masculinities (C. Hällgren, E. Dunkels and G-M. Frånberg, eds.), Umeå University, pp. 7-13, 2015. And at http://www.invisibleboy.org Retrieved 26 September 2018.

[23] A. Smith, The Theory of Moral Sentiment. Or, An Essay Towards An Analysis Of The Principles By Which Men Naturally Judge Concerning the Conduct and Character, First Of Their Neighbors, And Afterwards Of Themselves. S. Dugald (Editor) London. Bohn's Standard Library, 1759/1853. http://ff-oll.s3.amazonaws.com/titles/2620/Smith_TMSLanguages1648_Bk.pdf Retrieved 26 September 2018.

[24] E. Goffman, The presentation of self in everyday life. New York: Doubleday, 1959.

[25] J. Butler, Gender trouble: feminism and the subversion of identity. New York: Routledge, 1990.

[26] J. Butler, "Performative Acts and Gender Constitution: An Essay in Phenomenology and Feminist Theory," Theatre Journal, vol. 40, no. 4, pp. 519-531, 1988. https://doi.org/10.2307/3207893 Retrieved 26 September 2018.

[27] K. Crenshaw, "Demarginalizing the Intersection of Race and Sex: A Black Feminist Critique of Antidiscrimination Doctrine, Feminist Theory and Antiracist Politics," University of Chicago Legal Forum, vol. 1989, no. 1, article 8, pp. 138-167, 1989. and at: http://chicagounbound.uchicago.edu/uclf/vol1989/iss1/8 Retrieved 26 September 2018.

[28] K. Crenshaw, "Mapping the Margins: Intersectionality, Identity Politics, and Violence against Women of Color," Stanford Law Review, Volume 43, number 6, pp. 1241-1299, 1991. and at https://doi.org/10.2307/1229039 Retrieved 26 September 2018.

[29] P. de los Reyes and D. Mulinari, Intersektionalitet: kritiska reflektioner över (o)jämlikhetens landskap. [Intersectionality: Critical Reflections about the Landscape of (In)Equality] Malmö: Liber, 2005.

[30] D. G. Solórzano and T. J. Yosso, "Critical Race Methodology: Counter-Storytelling as an Analytical Framework for Education Research", Qualitative Inquiry, vol. 8, no. 1, pp. 23-44, 2002. https://doi.org/10.1177/107780040200800103, Retrieved 26 September 2018.

[31] C. Hällgren, Researching and Developing Swedkid: A Swedish Case Study at the Intersection of the Web, Racism and Education. Dissertations in Educational Work. No 5, 2006. Faculty of Teacher Education. Umeå University. And at http://www.divaportal.org/smash/get/diva2:144306/FULLTEXT01.pdfResearching Retrieved 26 September 2018.

[32] H. D. Grotevant, N. Dunbar, J. K. Kohler, and A. M. Lash Esau, "Adoptive Identity: How Contexts Within and Beyond the Family Shape Developmental Pathways*," Family Relations: Interdisciplinary Journal of Applied Family Studies, vol. 49, no. 4, pp. 379-387, 2000. https://doi.org/10.1111/j.1741-3729.2000.00379.x, Retrieved 26 September 2018. 
[33] S, May, "Critical Multiculturalism and Cultural Difference Avoiding Essentialism," in Critical Multiculturalism Rethinking Multicultural and antiracist education. (S. May, ed.), London: Falmer Press Taylor and Francis Group, pp. 11-35, 1999.

[34] W. E. B. Du Bois, The Souls of Black Folk. Essays and Sketches. A.C. McClung and CO, 1903/1907. and at https://archive.org/details/soulsblackfolke00boisgoog Retrieved 27 September 2018.

[35] M. Foucault, Discipline and punish: the birth of the prison. (2n Vintage Books ed.) New York: Vintage Books, 1977/1995.

[36] M. Castells, Communication Power. Oxford: Oxford University Press, 2009.

[37] M. Foucault, Technologies of the self: a seminar with Michel Foucault. L. H. Martin, H. Gutman, and P. H. Hutton (Editors) Amherst: Univ. of Massachusetts Press, 1988.

[38] A. Giddens, Modernity and self-identity: self and society in the late modern age. Cambridge: Polity press, 1991.

[39] J. A. G. van Dijk, The network society: social aspects of new media. (2. ed.) London: Sage, 2006.

[40] M. McLuhan, Understanding Media: The Extensions of Man. New York: McGraw Hill, 1964.

[41] D. McQuail, McQuail's Mass Communication Theory. 6th Ed. London: Sage, 1983/2010.

[44] S. Turkle, Life on the screen: identity in the age of the Internet. New York: Simon and Schuster, 1995.

[43] L. Nguyen and K. Barbour, "Selfies as expressively authentic identity performance" First Monday, vol. 22, no. 11, 2017. http://firstmonday.org/ojs/index.php/fm/article/view/7745/6561 Retrieved 27 September 2018.

[44] A. Loveless and B. Williamson, Learning identities in a digital age: rethinking creativity, education and technology. London: Routledge, 2013.

[45] M. C. Larsen, 2016. An 'Open Source' Networked Identity. On Young People's Construction and Co-construction of Identity on Social Network Sites. In: M. Walrave, K. Ponnet, E. Vanderhoven, J. Haers, and B. Segaert (Editors) Youth 2.0: Social Media and Adolescence. Connecting, Sharing and Empowering. Springer, pp 21-39.

[46] Z. Papacharissi, A networked self: identity, community, and culture on social network sites. New York: Routledge, 2011.

[47] P. David Marshall, 2015a. "Intercommunication and Persona: The Intercommunicative Public Self," The International Journal of Interdisciplinary Studies in Communication, volume 10, number 1, pp. 23-31. And at https://doi.org/10.18848/2324-7320/CGP/v10i01/53601 Retrieved 27 September 2018.

[48] P. David Marshall, Monitoring Persona: Mediatized Identity and the Edited Public Self," Frame: Journal of Literary Studies, vol. 28, no. 1, pp. 115-133, 2015b. http://www.tijdschriftframe.nl/wpcontent/uploads/2017/08/Frame-28_1-Monitoring-Persona.pdf Retrieved 27 September 2018.

[49] D. C. Brabham, "Crowdsourcing as a Model for Problem Solving: An Introduction and Cases," Convergence: The International Journal of Research into New Media Technologies. Vol. 14, No. 1, pp. 75-90, 2008 https://doi.org/10.1177/1354856507084420 Retrieved 27 September 2018.

[50] D. C. Brabham, Crowdsourcing. The MIT Press Essential Knowledge Series. Cambridge, Massachusetts: MIT Press, 2013.

[51] J. Howe, 2006. "The Rise of Crowdsourcing", Wired, 1 June 2006, at http://www.wired.com/wired/archive/14.06/crowds.html Retrieved 27 September 2018.

[52] E. Estellés-Arolas and F. González-Ladrón-de-Guevara, "Towards an Integrated Crowdsourcing Definition", Journal of Information Science, vol. 38, no 2, pp. 189-200, 2012. https://doi.org/10.1177/0165551512437638 Retrieved 27 September 2018. 